\title{
FAKTOR ANGIOGENIK SOLUBLE FMS-LIKE TYROSINE KINASE-1 DAN VASCULAR ENDOTHELIAL GROWTH FACTOR PADA IBU HAMIL 8 - 20 MINGGU DENGAN RISIKO PREEKLAMPSIA
}

\author{
Sri Sulistyowati ${ }^{1}$, Soetrisno ${ }^{2}$, Supriyadi Hari Respati ${ }^{3}$, Bambang Eko Wiyono ${ }^{4}$
}

\begin{abstract}
Background: Preeclampsia is still the main cause for maternal and neonatal mortality or morbidity. Anti-angiogenic Soluble FMS-Like Tyrosine Kinase-1 (sFlt-1) and proangiogenic Endhothelial Vascular Growth Factor (VEGF) factors can be used as an early detection of preeclampsia due to itsrole in the pathogenesis of preeclampsia, so it can be used as one effort to reduce maternal or perinatal morbidity and mortality.

Objective: To analyze sFlt-1 and VEGF levels in the serum of normal pregnancy and pregnancy with preeclampsia risk in 8 - 20 weeks gestation.

Method: Observational analytic with cross sectional method performed at the Obstetrics and Gynecology, Dr. Moewardi Hospital/ Medical Faculty Sebelas Maret University Surakarta and Prodia laboratory since November December 2013. Number of samples studied was 30 samples, comprising 15 samples of normal pregnancy and pregnancy with preeclampsia risk with $8-20$ weeks of gestational age. The sFlt-1 and VEGF serum levels was assessed using ELISA and analyzed using t-test.

Result \& Discussion: Serum level of sFlt-1 in normal pregnancy is $(1252,17 \pm 564,65 \mathrm{ng} / \mathrm{ml})$, and in pregnancy with preeclampsia risk is $(1741,90 \pm 640,97 \mathrm{ng} / \mathrm{ml})$ with $\mathrm{p}=0,023$ serum level of VEGF in normal pregnancy was $96,88 \pm 144,29 \mathrm{ng} / \mathrm{ml}$ and in pregnancy with preeclampsia risk was 14,24 $\pm 8,73 \mathrm{ng} / \mathrm{ml}$ with $\mathrm{p}=0,044$.

Conclusion: sFlt-1 level is higher and VEGF level is lower in pregnant women with preeclampsia risk than normal pregnancy on $8-20$ weeks gestational age.
\end{abstract}

Keywords: Pregnancy, Preeclampsia Risk, sFlt-1, VEGF.

\begin{abstract}
ABSTRAK
Latar belakang: Preeklampsia saat ini masih merupakan masalah pada ibu hamil yang berhubungan dengan mortalitas dan morbiditas maternal dan perinatal. Faktor anti-angiogenik Soluble FMS-Like Tyrosine Kinase-1 (sFLt1) dan proangiogenik Vascular Endhothelial Growth Factor (VEGF) diduga dapat digunakan sebagai deteksi dini karena perannya dalam patogenesis preeklampsia, sehingga dapat digunakan sebagai upaya untuk mengurangi angka morbiditas dan mortalitas maternal dan perinatal.

Tujuan: Untuk menganalisis kadar sFIt-1 dan VEGF pada serum ibu hamil normal dan ibu hamil dengan risiko preeklampsia pada usia kehamilan 8 - 20 minggu.

Metode: Penelitian observasional analitik dengan metode Cross Sectional yang dilakukan di bagian Obstetri dan Ginekologi, RSUD Dr. Moewardi/ FK UNS, Surakarta dan Laboratorium Prodia mulai Nopember - Desember 2013. Jumlah sampel terdiri 30 yang terbagi menjadi 15 sampel ibu hamil normal dan dan 15 sampel ibu hamil dengan risiko preeklampsia usia gestasi 8 - 20 minggu. Masing-masing dianalisis kadar sFlt-1 dan VEGF pada serumnya dengan metode ELISA dan dianalisis menggunakan uji t.

Hasil \& Pembahaasan: Kadar serum sFlt-1 pada kehamilan normal (1252,17 $\pm 564,65 \mathrm{ng} / \mathrm{ml})$, kehamilan dengan risiko preeklampsia $(1741,90 \pm 640,97 \mathrm{ng} / \mathrm{ml})$ dengan nilai $\mathrm{p}=0,023$ dan kadar VEGF pada kehamilan normal $(96,88 \pm 144,29 \mathrm{ng} / \mathrm{ml})$, kehamilan dengan risiko preeklampsia $(14,24 \pm 8,73 \mathrm{ng} / \mathrm{ml})$ dengan nilai $\mathrm{p}=0,044$.
\end{abstract}

\footnotetext{
1,2,3,4 Sri Sulistyowati, Bagian Obgin FK UNS/ RSUD Dr. Moewardi, Jl. Kol. Sutarto 132 Surakarta. Telp. 08122968215, Email: elis_spog@yahoo.co.id
} 
Kesimpulan: Kadar sFlt-1 lebih tinggi dan kadar VEGF lebih rendah pada kehamilan dengan risiko preeklampsia dibanding kehamilan normal pada usia hamil 8 - 20 minggu.

Kata kunci: Kehamilan, Risiko Preeklampsia, sFlt-1, VEGF.

\section{PENDAHULUAN}

Preeklampsia ditandai dengan hipertensi (tekanan darah sistolik $>140 \mathrm{mmHg}$ dan diastolik $>90$ $\mathrm{mmHg}$ dengan proteinuria $(>30 \mathrm{mg} /$ liter urin atau $300 \mathrm{mg} / 24 \mathrm{jam}$ ) yang terjadi pada usia kehamilan $>20$ minggu. ${ }^{1}$ Di negara berkembang termasuk Indonesia angka kejadian preeklampsia sekitar 3-10\%. Di rumah sakit Dr. Moewardi Surakarta kematian ibu yang disebabkan oleh preeklampsia mulai tahun 2008 2013 cenderung meningkat yaitu $67,5 \%-69,2 \%$. ${ }^{2,3}$

Berdasarkan kejadiannya preeklampsia dibagi menjadi 2 yaitu early onset (terjadi sebelum usia kehamilan 34 minggu) dan late onset (terjadi setelah 34 minggu). ${ }^{4}$ Prevalensi preeklampsia yang terjadi awal adalah 5-20\%. Pada early onset ini ditemukan invasi trophoblas yang tidak adekuat, pulsatility index pada pemeriksaan Doppler meningkat, meningkatnya resistensi vaskular perifer plasenta serta meningkatnya sistolik dan diastolik pada arteria umbilikalis. Meskipun persentasenya lebih kecil dari pada late onset tetapi pada early onset luaran ibu maupun janin lebih buruk seperti terjadinya HELLP syndrome, eklampsia, bayi prematur, pertumbuhan janin terhambat sampai kematian ibu maupun janin. ${ }^{5}$

Faktor risiko preeklampsia yaitu nuliparitas $64 \%$ dan multiparitas $36 \% .{ }^{6}$ Pada multipara dengan riwayat preeklampsia pada kehamilan sebelumnya mempunyai risiko $40-50 \% .{ }^{7}$ Wanita dengan body mass index (BMI) lebih dari 35 sebelum hamil mempunyai risiko lebih dari 4 kali untuk terjadinya preeklampsia. $^{8}$

Preeklampsia mempunyai karakteristik adanya ketidak seimbangan angiogenik yang dapat memicu kerusakan pada plasenta dan kerusakan sistemik yang menyebabkan disfungsi endotel yang akan bermanifestasi menjadi beberapa gejala preeklampsia.

Soluble Fms-Like Tyrosine Kinase-1 (sFlt-1) disintesis oleh sel sitotrophoblas dan berhubungan dengan penurunan angiogenesis pada ibu, janin, dan kultur sel endotel. Kadar sFlt-1 meningkat 5 kali lebih tinggi pada preeklampsia berat dibandingkan dengan preeklampsia ringan. Meningkatnya sFlt-1 dapat digunakan sebagai prediktor terjadinya preeklampsia berat. Peran sFlt-1 dalam patogenesis preeklampsia mempunyai nilai prediktif dan implikasi diagnostik yang penting karena kadarnya mulai meningkat pada trimester 2 yang kemudian menjadi preeklampsia. Meningkatnya sFlt-12-4 kali dapat terjadi pada 4-5 minggu sebelum manifestasi preeclampsia. ${ }^{9}$ Dalam kehamilan normal kadar sFlt-1 menurun pada usia kehamilan 8-12 minggu sampai 16-20 minggu dan mulai meningkat secara bertahap pada usia kehamilan 20-30 minggu. Peningkatan sFlt-1 lebih cepat pada usia kehamilan 35-39 minggu dan kembali ketingkat normal setelah melahirkan. ${ }^{10}$

Vascular Endothelial Growth Factor (VEGF) memiliki peranan yang penting dalam patogenesis preeklampsia. Meskipun total VEGF sedikit meningkat pada preeklampsia tetapi VEGF terikat oleh sFlt-1 yang mengakibatkan VEGF yang beredar menjadi rendah. Meningkatnya sFlt-1 akan menyebabkan VEGF bebas yang beredar dalam sirkulasi menjadi rendah/ berkurang. ${ }^{11}$

Penelitian ini bertujuan untuk menganalisis kadar sFIt-1 dan VEGF pada serum ibu hamil normal dan hamil dengan risiko preeklampsia pada usia 820 minggu dan diharapkan dapat menjadi alat prediktor pada kasus preeklampsia. 


\section{METODE}

Penelitian ini merupakan observasional analitik dengan metode cross sectional, dilakukan di Bagian Obstetri dan Ginekologi RSUD Dr. Moewardi Surakarta mulai bulan Nopember - Desember 2013. Pemeriksaan kadar serum sFlt-1 dan VEGF menggunakan metode Enzyme-Linked Immunoassay (ELISA) di laboratorium Prodia.

Penelitian dilakukan pada ibu hamil dengan risiko preeklampsia dan hamil normal pada usia kehamilan 8-20 minggu untuk menganalisis kadar sFlt-1 dan VEGF pada serumnya. Sampel penelitian yaitu semua ibu hamil yang melakukan antenatal di rumah sakit Moewardi Surakarta dengan menggunakan teknik consecutive sampling yaitu setiap pasien yang memenuhi kriteria inklusi dan eksklusi sampai jumlah sampel terpenuhi. Besar sampel ditentukan berdasarkan replikasi dari Murti yaitu 30 sampel yang terdiri dari 15 ibu hamil dengan risiko preeklampsia dan 15 ibu hamil normal. ${ }^{12}$ Kriteria inklusi yaitu ibu hamil $8-20$ minggu, primigravida dan multigravida dengan riwayat preeklampsia, hipertensi kronis, diabetes mellitus, penyakit jantung, penyakit ginjal, obesitas (indeks masa tubuh diatas $25 \mathrm{~kg} / \mathrm{m}^{2}$ ). Kriteria eksklusi yaitu pasien yang tidak bersedia mengikuti penelitian ini. Semua sampel dilakukan pemeriksaan kadar serum sFlt-1 dan VEGF di laboratorium Prodia. Pemeriksaan kadar sFlt-1 menggunakan reagen Human Soluble VEGF R1/FIt-1 (Immunoassay Quantikine DRV 100) dan VEGF menggunakan reagen Human VEGF (Immunoassay Quantikine DVE 00). Analisis hasil dilakukan uji t dengan nilai kepercayaan $95 \%$.

\section{HASIL DAN PEMBAHASAN}

\section{Karakteristik Subjek Penelitian}

Tabel 1. Sebaran Data Subjek Penelitian

\begin{tabular}{lcccccc}
\hline \multicolumn{1}{c}{ Variabel } & N & Min & Max & Rerata & SD & Nilai p \\
\hline Usia ibu (tahun) & 30 & 20 & 38 & 28,17 & 4,69 & 0,93 \\
Indeks masa tubuh $\left(\mathrm{kg} / \mathrm{m}^{2}\right)$ & 30 & 19 & 25 & 22,00 & 1,78 & 0,29 \\
Usia kehamilan $(\mathrm{minggu})$ & 30 & 8 & 20 & 14,96 & 4,58 & 0,46 \\
Paritas & 30 & 0 & 3 & 1,43 & 1,01 & 0,05 \\
Tekanan darah sistolik (mmHg) & 30 & 110 & 130 & 119,17 & 8,10 & 0,07 \\
Tekanan darah Diastolik (mmHg) & 30 & 70 & 90 & 78,00 & 7,14 & 0,06 \\
Haemoglobin (gr/di) & 30 & 9,8 & 12,7 & 11,26 & 0,81 & 0,84 \\
Ureum (mg/di) & 30 & 20 & 50 & 32,63 & 6,53 & 0,12 \\
Kreatinin (mg/dl) & 30 & 0,2 & 0,9 & 0,59 & 0,18 & 0,62 \\
SGOT (U/l) & 30 & 12 & 32 & 23,83 & 4,98 & 0,80 \\
SGPT (U/l) & 30 & 11 & 32 & 21,10 & 5,03 & 0,78 \\
Gula darah sewaktu (mg/dl) & 30 & 76 & 107 & 91,33 & 10,21 & 0,67 \\
\hline
\end{tabular}

* Signifikansi $p<0,05$

Uji normalitas Kolmogorov-Smirnov pada Tabel 1 menggunakan tingkat signifikansi $p<0,05$ karakteristik subjek penelitian usia ibu, indeks masa tubuh, usia kehamilan, paritas, tekanan darah sistolik, tekanan darah diastolik, hemoglobin, ureum, kreatinin, SGOT, SGPT, dan gula darah sewaktu terdistribusi normal $(p>0,05)$ sehingga semua sampel homogen. 
Tabel 2. Uji Beda Rerata Kelompok Kehamilan dengan Risiko Preeklampsia dan Kehamilan normal.

\begin{tabular}{|c|c|c|c|c|c|}
\hline Variabel & Kelompok & $\mathrm{N}$ & Rerata & SD & $\mathrm{p}$ \\
\hline \multirow{2}{*}{ Usia ibu (tahun) } & Normal & 15 & 29,73 & 4,10 & \multirow{2}{*}{0,07} \\
\hline & Risiko Preeklampsia & 15 & 26,60 & 4,85 & \\
\hline \multirow{2}{*}{ Indeks masa tubuh $(\mathrm{kg} / \mathrm{m} 2)$} & Normal & 15 & 22,07 & 1,91 & \multirow{2}{*}{0,84} \\
\hline & Risiko Preeklampsia & 15 & 21,93 & 1,71 & \\
\hline \multirow{2}{*}{ Usia kehamilan (minggu) } & Normal & 15 & 14,69 & 4,51 & \multirow{2}{*}{0,75} \\
\hline & Risiko Preeklampsia & 15 & 15,23 & 4,78 & \\
\hline \multirow{2}{*}{ Paritas } & Normal & 15 & 1,93 & 0,70 & \multirow{2}{*}{$0,00^{*}$} \\
\hline & Risiko Preeklampsia & 15 & 0,93 & 1,03 & \\
\hline \multirow{2}{*}{ Tekanan darah sistolik (mmHg) } & Normal & 15 & 120,00 & 8,45 & \multirow{2}{*}{0,58} \\
\hline & Risiko Preeklampsia & 15 & 118,33 & 7,94 & \\
\hline \multirow{2}{*}{ Tekanan darah sistolik (mmHg) } & Normal & 15 & 76,00 & 7,37 & \multirow{2}{*}{0,13} \\
\hline & Risiko Preeklampsia & 15 & 80,00 & 6,55 & \\
\hline \multirow{2}{*}{ Hemoglobin (gr/dl) } & Normal & 15 & 11,51 & 0,86 & \multirow{2}{*}{0,09} \\
\hline & Risiko Preeklampsia & 15 & 11,01 & 0,70 & \\
\hline \multirow{2}{*}{ Ureum (mg/dl) } & Normal & 15 & 32,13 & 4,45 & \multirow{2}{*}{0,68} \\
\hline & Risiko Preeklampsia & 15 & 33,13 & 8,24 & \\
\hline \multirow{2}{*}{ Kreatinin (mg/dl) } & Normal & 15 & 0,60 & 0,11 & \multirow{2}{*}{0,85} \\
\hline & Risiko Preeklampsia & 15 & 0587 & 0,24 & \\
\hline \multirow{2}{*}{ SGOT (U/I) } & Normal & 15 & 23,40 & 3,72 & \multirow{2}{*}{0,64} \\
\hline & Risiko Preeklampsia & 15 & 24,27 & 6,09 & \\
\hline \multirow{2}{*}{ SGPT (U/I) } & Normal & 15 & 17,00 & 4,02 & \multirow{2}{*}{$0,00^{*}$} \\
\hline & Risiko Preeklampsia & 15 & 23,20 & 3,97 & \\
\hline \multirow{2}{*}{ GDS } & Normal & 15 & 93,60 & 10,19 & \multirow{2}{*}{0,23} \\
\hline & Risiko Preeklampsia & 15 & 89,07 & 10,07 & \\
\hline
\end{tabular}

*Signifikansi $p<0,05$

Hasil uji beda rerata kelompok hamil dengan risiko preeklampsia dan hamil normaltidak terdapat perbedaan yang signifikan untuk variabel usia ibu, indeks masa tubuh, usia hamil, tekanan darah sistolik, tekanan darah diastolik, kadar hemoglobin, ureum, kreatinin, SGOT dan gula darah $(p>0,05)$, tetapi terdapat berbedaan yang signifikan untuk variabel paritas dan SGPT $(p<0,05)$ 
Kadar sFlt-1 dan VEGF pada Ibu Hamil dengan Risiko Preeklampsia dan Hamil Normal pada Usia Hamil 8-20 Minggu

Dari Tabel 3 diperoleh hasil distribusi rerata kadar sFlt-1 pada hamil dengan risiko preeklampsia lebih tinggi $(1741,90 \pm 640,97 \mathrm{ng} / \mathrm{ml})$ dibandingkan dengan hamil normal $(1252,17 \pm 564,65 \mathrm{ng} / \mathrm{ml})$ dengan $\mathrm{p}=0,03$ $(p<0,05)$. Distribusi rerata kadar VEGF tampak lebih rendah pada kehamilan dengan risiko preeklampsia $(14,24 \pm 8,73 \mathrm{ng} / \mathrm{ml})$ dibanding dengan hamil normal $(96,88 \pm 144,29 \mathrm{ng} / \mathrm{ml})$ dengan nilai $p=0,04(p<0,05)$.

Tabel 3.Kadar sFlt-1 dan VEGF pada Ibu Hamil dengan Risiko Preeklampsia dan Hamil Normal pada Usia Hamil 8-20 minggu

\begin{tabular}{cccr}
\hline Kadar serum & Risiko preeklampsia (n:15) & Normal (n:15) & P \\
\hline sFlt - 1 (ng/ml) & $1741,90 \pm 640,97$ & $1252,17 \pm 564,65$ & $0,03^{*}$ \\
VEGF $(\mathrm{ng} / \mathrm{ml})$ & $14,24 \pm 8,73$ & $96,88 \pm 144,29$ & $0,04^{*}$ \\
\hline
\end{tabular}

Faktor risiko terjadinya preeklampsia antara lain primigravida, adanya riwayat preeklampsia pada keluarga, riwayat preeklampsia berat pada kehamilan sebelumnya, hipertensi kronis, diabetes melitus dan hiperlipidemia. ${ }^{2}$ Primigravida frekuensinya lebih tinggi bila dibandingkan dengan multigravida, terutama primigravida muda. ${ }^{13}$

Pada preeklampsia terdapat ketidak seimbangan antara proangiogenik dan antiangiogenik. Dalam beberapa studi yang telah dipublikasikan, faktor proangiogenik dan antiangiogenik beredar pada saat sebelum terjadinya preeklampsia. ${ }^{14}$ Protein antiangiogenik yang beredar di sirkulasi maternal secara berlebihan dan bertanggung jawab untuk terjadinya preeklampsia yaitu Fms-like tyrosine kinase-1 (sFlt-1) dan Endoglin (sEng). ${ }^{9}$ Pada preeclampsia, terjadi peningkatan sFlt-1 yang menangkap VEGF bebas dan PIGF yang menyebabkan pembuluh darah abnormal pada ginjal, otak, dan paru-paru terganggu.

Peningkatan sFlt-1 dalam sistem sirkulasi berkontribusi untuk terjadinya preeklampsia. Pada saat meningkatnya sFlt-1 dan menurunnya kadar VEGF plasma di bawah ambang batas dapat menyebabkan disfungsi endotel sehingga terjadi gangguan sawar darah otak dan menimbulkan intrakranial hipertensi, edema, efek pada liver dan fungsi glomerulus. Disfungsi endotel berperan dalam regulasi hemostasis dan dapat memicu terjadinya trombositopenia. ${ }^{11}$

Meningkatnyas Flt-1 pada preeklampsia belum diketahui secara pasti tetapi faktor genetik, hipoksia, dan imunologi diduga sebagai penyebabnya. Kadar sFlt-1 meningkat sebagai respons terhadap adanya hipoksia. Selama kehamilan normal hipoksia relatif plasenta pada awal kehamilan kemudian menghilang seiring dengan peningkatan laju darah ke plasenta selama trimester kedua. Pada penelitian ini kadar sFlt-1 lebih tinggi pada kelompok kehamilan dengan risiko preeklampsia usia 8-20 minggu dibanding dengan kehamilan normal pada usia kehamilan yang sama. Rana dalam penelitiannya mendapatkan peningkatan sFlt-1 selama trimester pertama dan trimester kedua pada kehamilan dengan risiko preeklampsia, berbeda dengan kehamilan normal di mana kadar sFlt-1 pada trimester dua tetap atau bahkan menurun. Hal ini mendukung gagasan bahwa hipoksia plasenta berperan penting dalam meningkatkan produksi antiangiogenik pada preeklampsia. ${ }^{15}$ 
Peran sFlt-1 dalam patogenesis preeklampsia memiliki nilai prediktif dan implikasi diagnostik yang penting. Konsentrasi meningkat pada trimester ke dua mulai 4- 5 minggu sebelum manifestasi klinis terjadinya preeklampsia dan konsentrasinya meningkat 2 sampai 4 kali dibanding dengan kehamilan normal. ${ }^{6,9}$ Soluble fms-like tyrosine kinase 1 (sFlt-1) adalah protein antiangiogenik yang meningkat pada plasenta dan serum wanita preeklampsia. Pada usia kehamilan yang sama, kadar sFlt-1 secara signifikan lebih tinggi pada preeklampsia dibandingkan dengan kehamilan normal dan kadar sFlt-1 meningkat 5 minggu sebelum onset preeklampsia. ${ }^{16}$ Kadar sFlt-1 lebih tinggi pada early onset preeklampsia dibandingkan dengan late onset preeklampsia. Wanita dengan preeklampsia kadar sFlt-1 meningkat dan VEGF dan PIGF menurun kadarnya. ${ }^{17}$ Penelitian ini juga mempunyai hasil yang sama dengan Heazell yang menemukan kadar sFlt-1 meningkat pada usia 16 - 20 minggu kehamilan sebelum terjadinya preeklampsia. ${ }^{18}$

Vascular Endothelial Growth Factor (VEGF) memiliki peran yang sangat penting dalam patogenesis preeklampsia. Meskipun telah ditemukan bahwa total VEGF sedikit meningkat pada preeklampsia, tetapi VEGF terikat oleh sFlt-1 sehingga kondisi ini mengakibatkan kadar VEGF rendah selama preeklampsia. ${ }^{11}$

Ketidak seimbangan faktor angiogenik memainkan peran penting dalam patogenesis preeklampsia. Gangguan implantasi plasenta menyebabkan remodeling vaskuler menjadi dangkal yang mengakibatkan gangguan pseudovaskulogenesis yang diduga terjadi pada usia kehamilan 1218 minggu dan berperan penting dalam kejadian preeklampsia onset dini.

Pada awal kehamilan terjadi peningkatan jumlah leukosit dalam sel desidua termasuk sel - sel Natural Killer (NK) dan makrofag. Sel NK di uterus pada trimester pertama mensekresi VEGF yang cukup. Sel NK uterus merupakan sumber utama faktor angiogenesis di permukaan janin ibu selama awal kehamilan dan mempunyai peran penting untuk renovasi vaskular. Vascular Endothelial Growth Factor berperan dalam awal angiogenesis dan vaskulogenesis plasenta yang berlangsung hingga 24 minggu kehamilan. Setelah itu, percabangan angiogenesis diatur oleh PIGF dengan cara mengikat sFlt-1. Selain itu VEGF juga bertindak untuk mengatur remodelling arteria spiralis maternal. Kadar VEGF dan sFlt-1 merupakan dua reseptor yang berbeda selama kehamilan. Pada awal kehamilan VEGF kadarnya meningkat dan menurun pada akhir kehamilan, sedangkan PIGF dan sFlt-1 kadarnya meningkat seiring dengan meningkatnya usia kehamilan. ${ }^{4} \mathrm{Pada}$ penelitian ini kadar VEGF lebih rendah pada kehamilan dengan risiko preeklampsia dibanding dengan kehamilan normal pada usia 8-20 minggu. Penelitian yang dilakukan sebelumnya oleh Ahmad juga mendapatkan hasil yang sama dengan penelitian ini yaitu kadar VEGF menurun 53\% pada preeklampsia bila dibanding dengan kehamilan normal. 19,4,20,21 $^{2}$

\section{KESIMPULAN DAN SARAN}

Kadar sFlt-1 lebih tinggi dan kadar VEGF lebih rendah pada kehamilan dengan risiko preeklampsia dibanding kehamilan normal pada usia kehamilan 8 -20 minggu.

\section{DAFTAR PUSTAKA}

1. Sulistyowati S, Abadi A, Hood Julianto, Soetjipto. The Influence of Low HLA-G Protein Expression on Hsp-70 and VCAM-1 Profile in Preeclampsia. Indones J Obstet Gynecol. 2010 October 34(4):18590.

2. Sulistyowati S. 2010. Ekspresi Protein MHC Klas Ib (HLA-G \& Qa-2) yang Rendah Terhadap Profil Hsp70, VCAM-1, dan MMP-9 pada Preeklampsia. Penelitian Pada Ibu Hamil dan Hewan Coba Mus Musculus dengan Model Disfungsi Endotel. [Desertasi] Surabaya: Universitas Airlangga; 2010.

3. Sunaryo R, Bewiyono. Luaran Maternal pasien preeklampsia berat di Rumah sakit Dr. Moewardi Surakarta pada tahun 2012 pada program jaminan persalinan. 2013 
4. Krysiak O, Bretschneider A, Zhong E, Webb J, Hopp $\mathrm{H}$, Verlohren $\mathrm{S}$, at al. Soluble vascular endothelial growth factor receptor-1 (sFlt-1) mediates downregulation of Flt-1 and prevents activated neutrophils from women with preeclampsia from additional migration by VEGF. Circ Res. 2005 Dec 9;97(12):1253-61

5. Huppertz B.Placental origins of preeclampsia: challenging the current hypothesis. Hypertension. 2008 Apr;51(4):970-5

6. Matsubara K,Matsubara Y, Ito M.The utility of Vascular Dysfunction Studies in the Prediction and Prevention of Preeklampsia: Historical Review. Vascular Disease Prevention. 2009;6:163-9

7. Noori M, Savvidou M, Williams DJ. Endothelial factors. Cambridge University Press: Cambridge; 2007. Preeclampsia; Etiology and Clinical Practice; 50-77.

8. Yuan HT, Haig D, Ananth Karumanchi S. Angiogenic Factors in the Pathogenesis of Preeclampsia. Curr Top Dev Biol. 2005;71:297-312.

9. Karumanchi SA, Lindheimer MD. Preeclampsiapathogenesis: "triple a rating"-autoantibodies and antiangiogenicfactors. Hypertension. 2008 Apr;51 (4):991-2.

10. Escudero C, Puebla C, Westermeier F, Sobrevia L. Potential Cell Signaling Mechanisms Involved in differential Placental Angiogenesis in mild and severe Pre-eclampsia.Curr Vasc Pharmacol. 2009 Oct;7(4):475-85.

11. Lam $C^{1}$, Lim KH, Karumanchi SA. Circulating Angiogenic factors In the Pathogenesis and Prediction of Preeclampsia. Hypertension. 2005 Nov;46(5):1077-85.

12. Murti B. Desain dan ukuran sampel untuk penelitian kuantitatif dan kualitatif di orang kesehatan. Edisi ke-2. Gajah Mada University Press;2010. hlm.108 21.

13. Rozikhan. Faktor-faktor risiko terjadinya preeklampsia berat di rumah sakit Dr.H.Soewondo Kendal. [Tesis] Semarang: Universitas Diponegoro; 2007.

14. Barton, John R, Sibai, Baha M. Prediction and prevention of reccurent preeclampsia. Clinical expert series obstetric and gynecologic. 2008 August 112;2(1):359-72.

15. Rana S, Karumanchi SA, Levine RJ, Venkatesha S, Rauh-Hain JA, Tamez H. Sequential changes in antiangiogenic factors in early Pregnancy and Risk of developing Preeklampsia. American Heart Association. Hypertention. 2007;50:137-42.

16. Chen Y. Novel Angiogenic Factors for Predicting Preeclampsia: sFIt-1,PIGF, and Soluble Endoglin. The Open Clinical Chemistry Journal. 2009;2:1-6.

17. Varughese B, Bhatla N, Kumar R, Dwivedi SN, Dhingra R. Circulating Angiogenic Factors in pregnancies complicated by preeclampsia. Natl Med J India. 2010 Mar-Apr;23(2):77-81.

18. Heazell A, Norwitz ER, Kenny LC. Hypertension in Pregnancy. Cambridge University Press. 2010

19. Ahmad S, Ahmed A. Elevated placental soluble vascular endothelial growth factor receptor-1 inhibits angiogenesis in preeclampsia. Circ Res. 2004 Oct 29;95(9):884-91

20. Kim SY, Ryu HM, Yang JH, Kim MY, Han JY, Kim JO, et al. Increased sFlt-1 to PIGF ratio in women who subsequently develop preeclampsia. J Korean Med Sci. 2007 Oct;22(5):873-7.

21. Zhou Q, Liu H, Qiao F, Wu Y, Xu J.VEGF deficit is involved in endothelium dysfunction in preeclampsia. J Huazhong Univ Sci Technolog Med. 2010 Jun 17;30(3):370-4. 